\title{
(Ekpo) Masquerade In Edo Belief: The Socio - Economic Relevance
}

\author{
T. O. Ebhomienlen and M. O. Idemudia
}

\begin{abstract}
This paper examines EKPO (masquerade) among the Edo and its socio-economic contributions to development. It sees EKPO Cult and its Festivals as a vehicle for social stability and cohesion. Masquerades features prominently in African traditional religions. It is not out of place to assert that the preponderance of masquerades in most African Socio-religious Cult is a reflection of their unitary mode of expressing that which they perceive and thought of the divine or out of the sphere of humans. The African recognizes the place of the ancestors and gives them appropriate veneration and reverence as they are seen as human representatives in the spirit world. This paper further seeks to reveal that masquerade is one of the ways the African use to convey the continuous participation of the ancestors in human affairs. Hence, the Yoruba and the Edo conceive of masquerades as visible symbolic representation of the ancestors. They consider them as sacred and special cult is accorded them. To both people, Masquerade is a bridge of the chasm between the living and the living dead. The literature also discusses that masquerade though a spiritual phenomenon is also a vehicle for Socioeconomic development among the Edo people. The thrust of this paper is in this regards. A comparative and evaluative method is adopted in the crux of the discourse. The work succinctly submits that EKPO among the Benin like Egungun among the Yoruba is a vehicle for social cohesion, stability and development.
\end{abstract}

\section{Introduction:}

The patterns of behavior and thinking that people living in social groups learn, create and share in common, is what scholars in anthropology refers to as culture ${ }^{1}$. It encompasses the totality of all that make a people distinct from others and even animals. These distinctive characters may include: beliefs, style of dressing, kinds of food, Language, religion, music, dances, arts, technology, occupation, etc. these features define a person as a group member ${ }^{2}$.

The African are known for their rich and unique cultural appreciation. They express and reflect this in all their Socio - religious and even economic engagements. The African traditional religion receives a wide subscription when discussions that borders on a subject like Masquerade is tabled. This is so because the Africans probably have a better understanding of the concept and practice compared to other people and cultures of the world.

It is amazingly illuminating to note that the ideal and concept of masquerades runs parallel in most African traditional beliefs. Belief in ancestors is one of the core doctrines of African traditional religion. The African conceives of the dead as living dead who at death now take abode in the spirit world.

Masquerades- EKPO and Egungun among the Benin and Yoruba, stand the attention of this current endeavour. The origin, practices of the Cult, the taboos, its nexus with festivals, its significance etc, are some of the questions that naturally agitates one's mind in the spectrum of this sort of discourse. This work seeks address some of these questions against the backdrop of the practice among the Edo and Yoruba.

\section{THE EDO AND THE YORUBA}

For a number of reasons the Edo - Benin are a distinguished indigenous group in Nigeria. They are one of the major nationalities in African ${ }^{3}$. They possess a remarkable culture from which the renowned bronze casting which has continue to marvel and inspire the world even in this modern time, is gotten. According to Aisien, "They occupy the heartland of the territorial patrimony of the Edo Race and constitute the people of the Benin kingdom. The principal town of the Edo people is Benin City and it is the ethnic rallying point of the race" . The word Edo is the Traditional name of the people while Benin is the name given to the people by the European Colonists. Both words are interchangeably used in this treatise.

In the present day Nigeria, the Benin people occupy Edo State in the South- South geo- political zone. Benin City apart, the Benin live in other compact village settlements ranging in size from small hamlets to towns of several thousand people 5 .

Interestingly, Edo State is bounded in the west by Ondo and Ekiti States - two Yoruba States. Unlike the Edo which only boast of a section of a single state in Nigeria, the Yoruba are a very large people making up the entire western part of Nigeria, (South- west geopolitical zone). 
The Yoruba people are among the most organized and coherent group of people in Africa. The importance of their contribution in Arts, religion, and most recently, academia, is very well attested world over ${ }^{6}$. The Yoruba occupies; Ondo, Ekiti, Oyo, Ogun, Lagos, Osun and Kwara states of Nigeria present day configuration. The Yoruba make up more than one- fifth of the total population of Nigeria ${ }^{7}$. The Benin and the Yoruba are very religious people. Religion permeates virtually all their life undertakings as African. Both people also provide the religious platform on which African traditional religion can better be understood.

\section{COMMON BELIEFS IN EDO}

The Benin believes in the physical world which they call "Agbon" or Aye" and spiritual world referred to as "Erinmwin". Agbon is the domain of human beings while Erinmwin is the abode of the spirit beings including the ancestors - the living dead. They also conceive of Erinmwin as the final home of all humans at the completion of the circle of reincarnation. The earth (world) is believed to be only a cosmic market from which individuals must retire home at closure. Hence, the synthetically connected proverbial expressions; "Eki madodo vbagbon, Agha dueki, tag ha yowa" and "Erinmwin o owa" - we are in the world as a market place, after which we must return home ${ }^{8}$. The basic thought of Yoruba beliefs.

The Benin also believes in life after death and in the active participation of the departed ancestor in all the activities of their erstwhile community. The re- appearance of the ancestor in the physical corporeal world to participate symbolically in the affairs of the community is what the Benin demonstrates by EKPO (masquerades). The Yoruba also hold this basic idea about Egungun.

This symbolic representation does more than remind the people of life hereafter. They are also means by which moral consciousness and ethical values are championed. The activities associated with the masquerades awaken a deep sense of responsibility and communal interest among the people. This usually leads to a high level of cooperation and the attendant effects of Socio- economic development in the community.

\section{EKPO AND EGUNGUN IN DIALOGUE}

Although masquerades are visible phenomenon among virtually all African communities, its appreciation and application is unique among the Benins and the Yorubas of Nigeria. The concept thrives abundantly among both people and their belief system. So much has been said about the striking similarities that exist in the Yoruba and Benin traditional beliefs and worship system. The case that both people share a common ancestral background is further accentuated in the light of these similarities. The similarity of EKPO among the Benin and Egungun among the Yoruba, is one of such parallels that attests and favours the claim that both people have had something in common in the distant past.

As already noted in the foregoing sections, EKPO is an ancestral cult shoeing the belief of the Benin in life after death. The concept compares favourably with Egungun among the Yoruba. When asked, "what is there to Egungun?" a Yoruba man said;

The dead are not dead, so we believe. All over Yoruba land we share the same beliefs that the Egungun represent the spirit of the ancestors who have descended from heaven/ mountains. It is a period when the dead interact with the living ${ }^{9}$. Ancestors are assured a place for the dead among living. It is their responsibility to compel the living to uphold the ethical standards of past generations. Egungun is the celebration of Egungun and family ritual through the Masquerade ${ }^{10}$. The Egungun is a festival for the worship of the ancestors ${ }^{11}$.

The above glaringly reveals the similarities between the Benin EKPO and Yoruba Egungun.

Among the Efiks or the Ibibio of Nigeria, Masquerades are also called "EKPO". The beliefs and practices associated with it are not different from that of Benins and Yorubas.

Nigeria boasts of a plethora of customs and traditions, cultures and festivals, perhaps more than any other nation of the African and probably the world.

Thus, space will not permit us in this current undertaking to engage in drawing the nexus between EKPO and other masquerades in Nigeria Milieu. Succinctly put the EKPO and the Egungun among the Benins and the Yorubas respectively, designates the continuous participation of the spirit of the departed ancestors in the affairs of their human relations. Both are connected with ancestral worship and demonstrate the belief in the unbroken relationship between man and the spirit of the departed members of the community ${ }^{12}$. Death therefore, is not an end to human existence but only a passage or a transition from the material world to the spirit world with a continuum in interaction between both worlds ${ }^{13}$.

\section{THE ORIGIN OF EKPO AMONG BENINS}

The origin of $E K P O$ is shrouded in antiquity as there are variegated versions of the folklores connected to its emergence. However, two popular versions are found; the first is connected to Agboghidi of Ugo town in Edo State. He was a famous warrior who lived at the time of Oba Akegbuda in the middle of the eighteenth century ${ }^{14}$. Agboghidi was said to have returned to Ugo his town from several military campaign to meet a devastating epidemic. He became worried and prayed the ancestors to help cleanse the land. On a certain night 
he had a dream in which he saw Ekpo spirit walking through the major street of the town. He was then instructed to make emblem of EKPO to represent the spirit of the aggrieved ancestors and to offer sacrifices to appease them. He then made the EKPO shrine and instituted the cult in Ugo from where it is believed to have spread across other parts of Edo land ${ }^{15}$.

Unlike the first Version which situate the emergence of EKPO in a not too distance past, the second, which seems to be more correct, implies that Ekpo came into existence as a result of the need of the Benins to represent the spirits of the ancestors coming to the physical world in a symbolic way, to have communion with them. ${ }^{16}$. This belief also corroborates that of the Yorubas as revealed by Quarcoopome ${ }^{17}$ However, the two versions attest to EKPO as a symbolic representation of the ancestors. There is no doubt about this position among the Benins.

\section{THE YORUBA EGUNGUN: ORIGIN}

The fact already noted that the origin of masquerade is lost in antiquity also find expression in the discourse of Egungun among the Yorubas. Among the many folklores is this very stimulating one, of a mother who had a dozen children, and had lost all of them one after the other until only one 5- year old was left. She called him Oju meaning "my eye". Oju is said to have developed a strange habit of covering himself in his mother cloths from head to feet and dancing to the mother's Calabash bits at his request. When this was not done, Oju will fall ill. The mother on one of occasions, being afraid of losing her only son went to a local herbalist who after giving her medication instructed her to give her son whatever he demands. On getting home she made sack into clothing which covered oju leaving two small openings for him to see through. Oju who now danced to his taste quickly got well. After the death of his mother Oju kept her memory by making the habit a public show. This time, his friends join in the masquerading with drums beating without rhythm they would walk round the town. Gradually, other families in the village and surrounding towns copied that method of memorial celebration of their ancestors. Later, families in towns and villages combined to have one festival in remembrance of all the ancestors. The festival is called Egungun, meaning Masquerading and celebrating the ancestors ${ }^{18}$.

Again, the focal point in the foregoing is ancestors. The activities of the Egungun and Ekpo centre almost entirely on ancestral veneration and recognition.

\section{EKPO CULT IN BENIN LAND}

There is a special cult for Ekpo among the Benins and separate shrine dedicated exclusively for the cult and Ekpo worship. The shrines are always located in a hidden groove. It is here that the Ekpo regalia are kept. The non- initiates are not allowed to enter this groove hence no research attempt could discover and discuss everything about the cult. They are also barred from partaking in any sacrifice offered to the Masquerade. The shrine is presided over by a priest known as "Ohen Ekpo" who administers the affairs of the cult.

Membership of the Ekpo cult is reserved for only the males of the community. Generally, a boy of about twelve years and above can aspire to become a member of the cult known as Ovbiekpo (a child of Ekpo). At initiation, the aspirant is asked to pay some money as a token of commitment and readiness to assume responsibility in the cult. He also provides some cola- nuts, cowries and some gin for the ceremony. This is followed by the rituals and thereafter, the initiate is introduced to the rules governing the cult which is to keep secret from non initiates. From this point the new comer begins to see himself as a responsible agent to the ancestors on behalf of the entire community. He is not unaware of the grievous consequences of violating the rules and regulations guiding the cult. Since almost consciously violated the taboos of the community were either banished by Ekpo or at times eliminated. This made the people to be law abiding citizens before the era of what is now referred to as civilization brought by aliens

\section{EKPO FESTIVALS}

Although lgwe festival takes pre- eminence among the Benins there are however myriads of other festivals. The Ekpo festival is one of such. The festival varies in rituals and texture depending on the community and the divinity associated with the Ekpo cult.

Among the lguagban community of Ununmwode Local Government Area of Edo state, the Ekpo festival usually accompanies the lgwe festival held at the beginning of the New Year. Throughout the festival, the life of the community is renewed. The festival brings together the people as a group, thus, strengthening their unity and communal interest. The link between the living and the lining dead-ancestors are renewed ${ }^{20}$. The period affords the people the opportunity to offer prayers to the blessings and protection. Through the eating of a common ceremonial meal, the people strengthen their covenant with the ancestors and themselves on the other hand ${ }^{21}$. Thus, the community is reminded of the need to keep the standard of the ancestors. The festival brings to life the sense of participation and feeling that the people are in the presence of the divinities and under the watchful eyes of the ancestors. 


\section{EKPO FESTIVAL AND SOCIO- ECONOMIC DEVELOPMENT}

The value of a thing can only be accessed in its function(s). All cultic activities including Ekpo have duties they perform, since they have tenets and doctrinal principles for their adherents. It is upon such principles that the lives of the adherents are adjudged right or wrong. The Ekpo cult in particular instills in the people a thought pattern that marks for a valued one it is known as "Agbon esi". The concept is more than the English literal translation of a good life. It implies the total sum of one's entire span, so that when one is said to have lived "agbon esi" at death, such one had a passed mark in contributing to the socio - economic development and general wellbeing of his community and by implication, passes to the abode of the ancestors. The symbolic reappearance of the ancestors in Ekpo festivals, assures the members of the community that there is life after death and joining one's ancestors in peace, requires a good life, otherwise, one faces the consequence of becoming a wandering spirit at death. This belief makes the individual to be very courteous in his dealings with his fellow man. The belief also gives concrete expression to the ideal of community among the Benins, to be a human being is to belong to a community and of a necessity, participate in all that guarantees the progress and development of the community.

Among the Yorubas, the Egungun (masquerades) demonstrates both ethical and moral behaviors of the people, exposing the strengths and the weaknesses of the community with the hope of encouraging behaviours more benefiting of their descendants ${ }^{22}$. This is particularly true of Oloolu, and Alapansanpa both of lbadan land. There is no doubting the fact that good ethical conducts contribute in no small way to socio-economic development of a people. In business and other economic activities, the Yorubas and the Benins enjoyed a fair dealing with their people because of the principles of Egungun and Ekpo cult.

The Ekpo is force to reckon with especially when the peace and socio- economic life of the community is threatened or disturbed. For instance, at moments when stealing, adultery, incest, witchcraft activities, etc, are reported commonly, the Ekpo will make a sudden appearance to the community. At occasions like this, the Ekpo will walk through the major streets of the community at the glare of everyone. The appearance is usually devoid of the regular dancing and merriment associated with it. Rather, the Ekpo is arrayed with regalia and a mask that portrays anger and warnings. Thereafter, peace and order returns to the community and socio-economic activities bounces back to nomacy ${ }^{23}$.

The Ekpo festival particularly strengthens family and communal tiles. The period is usually marked with settlement of communal and individual differences and disputes. This is necessary because a person seeking a blessing from the ancestors must be in social harmony with the family members and the community. Consequently, the fear of the capabilities of the ancestors to punish offenders in community and family, make people behave and work as team for all round development ${ }^{24}$.

The Ekpo cult also emphasizes socio economic solidarity in the sense that members are committed to one another. For instance, a sick member of a group who is incapacitated by ill health to engage in any productive (economic) activities in his farm or other economic venture, is usually helped by other members until he is considered fit to resume such duties ${ }^{25}$.

The Ekpo cult stresses the importance of the young (youth). It is normally controlled by the group known as lroghea- the males from about twelve years to about thirty years at the direction of the Edion - the elders and the Ohen - priest. The youth are instructed on hard work and dedication to assigned duties by the elders. The expression, "aimien eghele ne obohe ma vbe" meaning "there is no youth without a wide palm", is a proverb that sufficiently captions the dutifulness and vibrancy of the Benin Youth. Thus, from the Ekpo cult, the youth learn how to become economically relevant and responsible to his family and the community at large ${ }^{26}$.

\section{EKPO CULT AND THE SOCIETY TODAY}

Looking at the general moral decadence in Nigeria society today, one would not but wished that there be a revival of some of our traditional cultures and practices. Suffice it to say that the problems in the society, especially of the endemic corruption and avarice which has found itself into the social lexicon of the people, is not less than a reflection of the failure of some foreign culture in addressing Nigeria peculiar needs. Ekpo cult emphasizes principles that strengthen social values and cohesion. It prohibits practices such as fighting, quarreling, cheating, stealing, etc, considered inimical to, and unethical for the progress and continuous development of the community. These prohibitions are strictly followed because they are embedded in the initiation rite. Viewed against the present day Nigeria society, the cult seems to be a perfect solution if revived. To us, the problem of Nigeria is not more than that of moral irresponsibility occasioned by erosion of our traditional values and culture which if revived will lead to a drastic change of attitudes.

The Ekpo cult also stresses the need for the youth to be active participators in the developmental process of the community. They are carried along and given appropriate recognition. This is diametrically opposed to today's society where the youth are left unattended and unemployed. The effects of this in the society stares us in the 
face. Robbery, kidnappings, cyber crimes, militancy, and such the likes, are some of the ripple effects of government continuous insensitivity to the yearnings of the teaming youths.

The core belief in life hereafter in traditional religions is now almost entirely being swallowed up by the avaricious and hedonistic proclivities imbibed from western culture. This has resulted in "I don't care attitude".

\section{WAY FORWARD}

(1) We want to strongly advocate the revival of some of our cultural values and practices as veritable means through which some of these perennial problems faced in our society today may be addressed. Attention should be given to some traditional festivals by government at all levels. These festivals should be aired on television and even the internet.

(2) The government at all levels should begin to consider the potential economic viability of some of our traditional culture as a way of boosting the tourism sector.

(3) Leaders must drop their pride and learn from traditional institutions and principles for sustainable development.

(4) Traditional rulers must be given adequate recognition among their people. The government can begin by giving them space in governance.

(5) More importantly traditional festivals should be adequate attention because of the positive role it plays in socio-economic development.

\section{Conclusion}

In this paper we discussed the similarity which exists between Egungun and Ekpo. The relationship and brotherhood of all Africa Ethnic groups is evident in their cultural manifestations. The Egungun and Ekpo cults among the Yorubas and the Edo people show their strong belief in ancestors and their capability to punish and reward. Sufficiently, this paper reveals that these cults play socio- economic roles among the people such as preventing the adherent from social vices, helping handicapped members, creating room for communal integration and solidarity and bridging the gap between life and death. This makes the people to connect good living with good death and eventually joining the ancestors which the ultimate aspiration of an African. Thus this contributed immensely to the cordial relationship which existed among the traditional African. If ideal development must resume in Africa, the African practices and values must be given new impetus.

\section{Works cited}

[1]. C. G. Fredrick, "Culture” The Encyclopaedia of Americana 8, (U S A: Grolier Incorporated 1997), 134.

[2]. Fredrick, 134 .

[3]. C. O. Okojie, Esan Native Laws and Customs with Ethnographic Studies of the Esan People (Benin City: llupeju Press Ltd 1994), 24 .

[4]. B. E. Asien The Benin People, (Benin City: Spectrum Books Ltd, 206), 19.

[5]. R. E. Bradbury, The Benin Kingdom and the Edo speaking People of Southern Nigeria (London: Wightman Mountain 1970 ), 26.

[6]. R. A. Ogunleye "Covenant- making in Yoruba Traditional Religion: A Panacea for moral Decadence in Nigeria, a Ph D. Thesis Submitted to Department of Religious Management and Cultural Studies (A.A.U., Ekpoma Edo State 2008), 5.

[7]. Ogunleye, 6

[8]. Chief M. O. Obaro, Oral interview at Benin City on $18^{\text {th }}$ July, 2011.

[9]. S. O. Olufemi, Oral interview at Ekpoma on $13^{\text {th }}$ July, 2011.

[10]. Olufemi

[11]. Olufemi

[12]. T. N. O. Quarcoopome, West African Traditional Religion, (Ibadan: African University Press 1987), 187.

[13]. J. O. Awolalu and P. A Dopamu, West African Traditional Religion, (Ibadan: University Press 1978), 253.

[14]. D. O. Aghahowa, Oral interview at Benin City on $21^{\text {st }}$ June, 1999.

[15]. Abhaowa

[16]. F. E. Idemudia, Oral interview at Benin City $16^{\text {th }}$ July, 2011

[17]. Quarcoopome, 183.

[18]. J.O.Osasona, Oral Interview at Benin City on $16^{\text {th }} \mathrm{July}, 2011$

[19]. Pa L. O. Agbonghese Oral interview at Uromi on $13^{\text {th }}$ July, 2011.

[20]. Aghahowa

[21]. Pa Odumo, Oral interview at Benin City on $16^{\text {th }}$ July, 2011.

[22]. Bradbury, 57.

[23]. Pa Odiase, Oral interview at Benin City on $16^{\text {th }}$ July, 2011.

[24]. Odiase

[25]. Odiase

[26]. S. O. Edobor, Festivals in Benin Kingdom (Benin City: Apha Press nd), 36. 